\title{
Identification of Loci of Pseudomonas syringae pv. actinidiae Involved in Lipolytic Activity and Their Role in Colonization of Kiwifruit Leaves
}

\author{
Hitendra Kumar Patel, Patrizia Ferrante, Meng Xianfa, Sree Gowrinadh Javvadi, Sujatha Subramoni, \\ Marco Scortichini, and Vittorio Venturi
}

First, third, fourth, fifth, and seventh authors: International Centre for Genetic Engineering and Biotechnology, Trieste, Italy; second and sixth authors: Research Centre for Fruit Crops, Agricultural Research Council, Roma, Italy; and sixth author: Research Unit for Fruit Trees, Council for Agricultural Research and Economics, Caserta, Italy.

Current address of first author: CSIR-Centre for Cellular \& Molecular Biology, Habsiguda, Uppal Road, Hyderabad-500 007, Telangana State, India.

Current address of third author: Integrative Microbiology Research Centre, South China Agricultural University, Guangzhou 510642, China.

Current address of fifth author: Singapore Centre for Environmental Life Sciences Engineering (SCELSE) Nanyang Technological University,

60 Nanyang Drive, SBS-01N-27, Singapore 637551.

Accepted for publication 18 January 2017.

\begin{abstract}
Bacterial canker disease caused by Pseudomonas syringae pv. actinidiae, an emerging pathogen of kiwifruit plants, has recently brought about major economic losses worldwide. Genetic studies on virulence functions of $P$. syringae pv. actinidiae have not yet been reported and there is little experimental data regarding bacterial genes involved in pathogenesis. In this study, we performed a genetic screen in order to identify transposon mutants altered in the lipolytic activity because it is known that mechanisms of regulation, production, and secretion of enzymes often play crucial roles in virulence of plant pathogens. We aimed to identify the set of secretion and

mutants revealed that the transposons were inserted in genes that play roles in cell division, chemotaxis, metabolism, movement, recombination, regulation, signal transduction, and transport as well as a few unknown functions. Several of these identified $P$. syringae pv. actinidiae Tn 5 mutants, notably the functions affected in phosphomannomutase $\mathrm{AlgC}$, lipid A biosynthesis acyltransferase, glutamate-cysteine ligase, and the type IV pilus protein Pill, were also found affected in in planta survival and/or growth in kiwifruit plants. The results of the genetic screen and identification of novel loci involved in in planta fitness of $P$. syringae pv. actinidiae are presented and discussed.
\end{abstract} global regulatory loci that control lipolytic activity and also play important roles in in planta fitness. Our screen for altered lipolytic activity phenotype identified a total of $58 \operatorname{Tn} 5$ transposon mutants. Mapping all these Tn5
Additional keywords: bacterial canker of kiwifruit, emerging pathogen, virulence loci.
Gram-negative Pseudomonas plant-pathogenic bacteria are known to cause disease in a broad range of economically important host plants with a variety of disease symptoms. The Pseudomonas syringae group contain model pathogens that are distinguished into at least nine genomospecies and 60 pathovars (Gardan et al. 1999; Marcelletti and Scortichini 2014). Examples of three agriculturally important pathogens of this group are P. syringae pv. tomato DC3000 (Preston 2000), P. syringae pv. phaseolicola 1448A (Joardar et al. 2005), and P. syringae pv. syringae B728a (Hirano and Upper 2000). These have been widely studied and used as model systems to study the virulence functions in plant pathogen interactions. The majority of plant pathogenic pseudomonads studied are pathogenic to herbaceous plants while pathogens from woody plants have been understudied. The increasing economic value of woody plants and the growing knowledge of pathogens and hosts are now helping to address these diseases and their pathogens in woody plants.

In the past 2 decades, emerging and re-emerging plant pathogens have caused new threats to the production of several economically important crops. The kiwifruit pathogen $P$. syringae pv. actinidiae is an emerging woody plant pathogen that has recently received considerable attention due to its increasing incidence and global spread (Scortichini et al. 2012). P. syringae pv. actinidiae causes

Corresponding author: V. Venturi; E-mail address: venturi@icgeb.org

*The $\boldsymbol{e}$-Xtra logo stands for "electronic extra" and indicates that three supplementary figures and three supplementary tables are published online.

(c) 2017 The American Phytopathological Society canker or leaf spot on Actinidia plants (Serizawa et al. 1989) and was first described in Japan in 1984 (Takikawa et al. 1989) and later was isolated in South Korea (Koh et al. 1994) and Italy (Scortichini 1994). In 2008, a serious re-emergence of $P$. syringae pv. actinidiae was found on Actinidiae chinensis (kiwigold) plants in central Italy causing huge economic losses (Ferrante and Scortichini 2010). This outbreak was caused by a different population of $P$. syringae pv. actinidiae from the original one that caused fewer problems in 1992 (Marcelletti et al. 2011; Vanneste et al. 2010). P. syringae pv. actinidiae has also recently caused important outbreaks in several countries including China (Yang et al. 2015), Portugal (Balestra et al. 2010), France (Vanneste et al. 2011), Chile (Anonymous 2011), New Zealand ((Everett et al. 2011), Spain (Abelleira et al. 2011), Switzerland (EPPO 2011), and Turkey (Bastas and Karakaya 2012).

In plant-Pseudomonas pathogen interactions, several virulence factors contributing to bacterial pathogenicity have been studied in great detail. These include the type III secretion system (T3SS) (Hauser 2009) bacterial toxins (Lindeberg et al. 2008) and exopolysaccharides (Yu et al. 1999; Laue et al. 2006). Moreover, global regulatory mechanisms like quorum sensing, two component systems, and alternative sigma factors have also been found to play an important role in virulence of Pseudomonas pathogens. $P$. syringae pv. actinidiae studies are so far focused mainly on its identification and pathogen differentiation (Koh and Nou 2002; Koh et al. 2014; Lee et al. 2016), its origin, evolution and epidemic spread (Butler et al. 2013; Chapman et al. 2012; Ciarroni et al. 2015; Cunty et al. 2015; Mazzaglia et al. 2012; Scortichini et al. 2012; Vanneste et al. 2013), genome sequence analyses (Fujikawa and Sawada 2016; Marcelletti et al. 2011; McCann et al. 2013; Templeton et al. 2015), proteomic analyses of different host 
tissues (Petriccione et al. 2013, 2014), and its management either of using resistant host lines or use of bacteriophages (Di Lallo et al. 2014; Yu et al. 2016) and chemical compounds (Cameron et al. 2014; Ghods et al. 2015).

As very few genetic and molecular studies of $P$. syringae pv. actinidiae virulence have been performed (Cellini et al. 2014), we decided to perform an exhaustive screen of a Tn5 genomic mutant library of $P$. syringae pv. actinidiae for alteration of an easily discernable phenotype shown to be virulence-associated in other pathogenic bacteria. In phytobacteriology, mechanisms of regulation, production, and secretion of enzymes often play crucial roles in virulence of plant pathogens (Buttner and Bonas 2010; Chang et al. 2014; Poueymiro and Genin 2009). With this aim, we screened several thousands of transposon mutants for the secreted lipase/ esterase activity (lipolytic activity) phenotype. P. syringae pv. actinidiae mutants altered for lipolytic activity and the genes carrying insertions in these mutants were identified. Role of these genes in determining lipolytic activity phenotype was verified by generating independent mutants in identified genes and complementation analysis. The role of these genes were then assessed for their contribution to survival and/or growth of $P$. syringae pv. actinidiae in plant infection models; the results are presented and discussed.

\section{MATERIALS AND METHODS}

Bacterial strains, media, and culture conditions. The bacterial strains and plasmids used in this study are listed in Table 1 and Supplementary Table S1, respectively. $P$. syringae pv. actinidiae strain 10.22 is clonal to the $P$. syringae pv. actinidiae CRAFRU strains, which have been isolated in the province of Latina (central Italy) from spot lesions of A. chinensis (Ferrante and Scortichini 2010). P. syringae pv. actinidiae strains were grown at $25^{\circ} \mathrm{C}$ in Luria Bertani (LB), nutrient sucrose agar (NSA; composition for 1 liter: peptone $20 \mathrm{~g}$, sucrose $5 \mathrm{~g}$, K2HPO4 $0.5 \mathrm{gm}, \mathrm{MgSO} 4.7 \mathrm{H} 2 \mathrm{O} 0.25 \mathrm{~g}$, and agar $12 \mathrm{~g}$ ) or King's B medium (King et al. 1954). The concentrations of antibiotics used in this study were as follows: nitrofurantoin (Nf), $150 \mu \mathrm{g} / \mathrm{ml}$; kanamycin $(\mathrm{Km}), 50 \mu \mathrm{g} / \mathrm{ml}$; gentamycin $(\mathrm{Gm}), 30 \mu \mathrm{g} / \mathrm{ml}$; and tetracycline (Tc), $30 \mu \mathrm{g} / \mathrm{ml}$ for $P$. syringae $\mathrm{pv}$. actinidiae strains and $\mathrm{Km}, 50 \mu \mathrm{g} / \mathrm{ml}$; Gm, $15 \mu \mathrm{g} / \mathrm{ml}$; Tc, $15 \mu \mathrm{g} / \mathrm{ml}$; and ampicillin (Ap), $100 \mu \mathrm{g} / \mathrm{ml}$ for $E$. coli strains. P. syringae pv. actinidiae is naturally resistant to nitrofurantoin.
Recombinant DNA techniques. Routine DNA manipulation steps such as digestion with restriction enzymes, agarose gel electrophoresis, purification of DNA fragments, ligations with T4 ligase, Southern analysis, radioactive labeling by random priming, and transformation of $E$. coli were done using standard procedures as described previously (Sambrook et al. 1989). Colony hybridizations were performed using Hybond-N+ membrane (Amersham Biosciences); plasmids were purified using the EuroGold plasmid columns (Euro Clone) or with the alkaline lysis method (Birnboim 1983); total DNA from P. syringae pv. actinidiae strains were isolated by Sarkosyl/Pronase lysis as described previously (Better et al. 1983). PCR amplifications were performed using Go-Taq DNA polymerase or pfu DNA polymerase (Promega). The oligonucleotide primers used in this study are listed in Supplementary Table S2. Automated sequencing was performed by Macrogen sequence service (Europe). Triparental matings between E. coli and P. syringae pv. actinidiae were carried out with the helper strain E. coli DH5 $\alpha$ (pRK2013) (Figurski and Helinski 1979).

Generation of a $P$. syringae pv. actinidiae genomic Tn5 mutant library. Tn5 mutagenesis was performed by using triparental matings between donor $E$. coli (pSUP2021) containing the transposon $\mathrm{Tn} 5(\mathrm{Km}$ resistance), a helper E. coli strain (pRK2013), and recipient $P$. syringae pv. actinidiae strain. Briefly, $P$. syringae pv. actinidiae (strain 10.22) was grown overnight in $100 \mathrm{ml}$ of LB media supplemented with $\mathrm{Nf}$ at room temperature. Donor $E$. coli and helper $E$. coli strains were also grown overnight in $20 \mathrm{ml}$ of LB media supplemented with appropriate antibiotics at $37^{\circ} \mathrm{C}$. Cells of $P$. syringae pv. actinidiae, donor E. coli, and helper $E$. coli were pelleted, washed twice in plain $\mathrm{LB}$, and resuspended in $20 \mathrm{ml}$ of sterile LB media. The absorbance of all three strains was measured at $\mathrm{OD}_{600}$ and cells were mixed in the following ratio: recipient $P$. syringae pv. actinidiae, $2 \times 10^{8}$ colony forming units $(\mathrm{CFU} / \mathrm{ml})$; helper $E$. coli, $4 \times 10^{9} \mathrm{CFU} / \mathrm{ml}$; and donor $E$. coli, $4 \times 10^{9}$ $\mathrm{CFU} / \mathrm{ml}$. The mixture of cells was pelleted, resuspended in a small volume of LB media and spotted onto Hybond-N+ nylon membrane (Amersham Pharmacia Biotech) that was overlaid on LB agar. Overnight incubated cells grown at room temperature were scraped from the membrane and resuspended in $1 \mathrm{ml}$ of sterile LB media. The cell suspension $(50 \mu \mathrm{l}$ each) was plated on LB agar plates containing $\mathrm{Nf}$ and $\mathrm{Km}$. The plates were incubated at room temperature for 2 to 3 days to allow the growth of exconjugants

TABLE 1. Bacterial strains used in this study

\begin{tabular}{|c|c|c|}
\hline Strains & Relevant characteristics ${ }^{\mathrm{a}}$ & Reference/source \\
\hline \multicolumn{3}{|l|}{ Escherichia coli } \\
\hline $\mathrm{DH}_{5} \alpha$ & Cloning strain, $\mathrm{Nal}^{\mathrm{r}}$ & (Grant et al. 1990) \\
\hline C118 $\lambda$ pir & $\begin{array}{l}\Delta(\text { are-leu) araD } \Delta l a c X 74 \text { galE galK phoA } 20 \text { thi-1 rpsE rpoB argE recAl lysogenized } \\
\text { with } \lambda \text { pir phage }\end{array}$ & (Herrero et al. 1990) \\
\hline pRK2013 & Helper strain for triparental conjugation, $\mathrm{Km}^{\mathrm{r}}$ & (Figurski and Helinski 1979) \\
\hline \multicolumn{3}{|l|}{$\begin{array}{l}\text { Pseudomonas syringae pv. } \\
\text { actinidiae (Psa) }\end{array}$} \\
\hline Psa 10.22 & Wild type; Italian isolate; $\mathrm{Nf}^{\mathrm{r}}$ & Lab collection \\
\hline Psa Lap mutants & Psa::Tn5 mutants with alteration in lipase secretion, $\mathrm{Nf}^{\mathrm{r}}, \mathrm{Km}^{\mathrm{r}}$ & This work \\
\hline Psa Lap38-pKNOCK & Lap38::pKNOCK; $\mathrm{Nf}^{\mathrm{r}}, \mathrm{Km}^{\mathrm{r}}$; derivative of wild type & This work \\
\hline Psa Lap41-pKNOCK & Lap41::pKNOCK; $\mathrm{Nf}^{\mathrm{r}}, \mathrm{Km}^{\mathrm{r}}$; derivative of wild type & This work \\
\hline Psa Lap42-pKNOCK & Lap42::pKNOCK; $\mathrm{Nf}^{\mathrm{r}}, \mathrm{Km}^{\mathrm{r}}$; derivative of wild type & This work \\
\hline Psa Lap45-pKNOCK & Lap45::pKNOCK; $\mathrm{Nf}^{\mathrm{r}}, \mathrm{Km}^{\mathrm{r}}$; derivative of wild type & This work \\
\hline Psa Lap169-pKNOCK & Lap169::pKNOCK; $\mathrm{Nf}^{\mathrm{r}}, \mathrm{Km}^{\mathrm{r}}$; derivative of wild type & This work \\
\hline Psa Lap200-pKNOCK & Lap200::pKNOCK; $\mathrm{Nf}^{\mathrm{r}}, \mathrm{Km}^{\mathrm{r}}$; derivative of wild type & This work \\
\hline Psa Lap208-pKNOCK & Lap208::pKNOCK; $\mathrm{Nf}^{\mathrm{r}}, \mathrm{Km}^{\mathrm{r}}$; derivative of wild type & This work \\
\hline Psa Lap276-pKNOCK & Lap276::pKNOCK; $\mathrm{Nf}^{\mathrm{r}}, \mathrm{Km}^{\mathrm{r}}$; derivative of wild type & This work \\
\hline Psa Lap38+pCosLap38 & Psa Lap38 carrying cosmid clone for Lap38; $\mathrm{Nf}^{\mathrm{r}}, \mathrm{Km}^{\mathrm{r}}, \mathrm{Tc}^{\mathrm{r}}$; derivative of Psa Lap38 & This work \\
\hline Psa Lap41+pCosLap41 & Psa Lap41 carrying cosmid clone for Lap41; $\mathrm{Nf}^{\mathrm{r}}, \mathrm{Km}^{\mathrm{r}}, \mathrm{Tc}^{\mathrm{r}}$; derivative of Psa Lap41 & This work \\
\hline Psa Lap42+pCosLap42 & Psa Lap42 carrying cosmid clone for Lap42; $\mathrm{Nf}^{\mathrm{r}}, \mathrm{Km}^{\mathrm{r}}, \mathrm{Tc}^{\mathrm{r}}$; derivative of Psa Lap42 & This work \\
\hline Psa Lap45+pCosLap45 & Psa Lap45 carrying cosmid clone for Lap45; $\mathrm{Nf}^{\mathrm{r}}, \mathrm{Km}^{\mathrm{r}}, \mathrm{Tc}^{\mathrm{r}}$; derivative of Psa Lap45 & This work \\
\hline Psa Lap169+pCosLap169 & Psa Lap169 carrying cosmid clone for Lap $169 ; \mathrm{Nf}^{\mathrm{r}}, \mathrm{Km}^{\mathrm{r}}, \mathrm{Tc}^{\mathrm{r}}$; derivative of Psa Lap169 & This work \\
\hline Psa Lap200+pCosLap200 & Psa Lap200 carrying cosmid clone for Lap200; $\mathrm{Nf}^{\mathrm{r}}, \mathrm{Km}^{\mathrm{r}}, \mathrm{Tc}^{\mathrm{r}}$; derivative of Psa Lap200 & This work \\
\hline Psa Lap208+pCosLap208 & Psa Lap208 carrying cosmid clone for Lap208; $\mathrm{Nf}^{\mathrm{r}}, \mathrm{Km}^{\mathrm{r}}, \mathrm{Tc}^{\mathrm{r}}$; derivative of Psa Lap208 & This work \\
\hline Psa Lap276+pCosLap276 & Psa Lap276 carrying cosmid clone for Lap276; $\mathrm{Nf}^{\mathrm{r}}, \mathrm{Km}^{\mathrm{r}}, \mathrm{Tc}^{\mathrm{r}}$; derivative of Psa Lap276 & This work \\
\hline
\end{tabular}

${ }^{a} \mathrm{Nal}^{\mathrm{r}}, \mathrm{Km}^{\mathrm{r}}, \mathrm{Tc}^{\mathrm{r}}, \mathrm{Gm}^{\mathrm{r}}$, and $\mathrm{Nf}^{\mathrm{r}}$ indicate resistance to nalidixic acid, kanamycin, tetracycline, gentamycin, and nitrofurantoin, respectively. 
(Tn5 mutants). The $P$. syringae pv. actinidiae genomic Tn5 insertion mutants were then patched onto LB agar plates with $\mathrm{Nf}$ and $\mathrm{Km}$ and grown in liquid media with the similar set of antibiotics.

Screening of $P$. syringae pv. actinidiae Tn5 mutants for lipolytic activity. Lipolytic activity for $P$. syringae pv. actinidiae strains was performed as mentioned previously with some modifications (Smeltzer et al. 1992). Briefly, for plate assays $1 \mathrm{ml}$ of tributyrin (Sigma) solution was added to a $10 \mathrm{ml}$ of LB broth and sonicated using a sonicator (with four pulses of 60 to 80 Herts using a Bandeline Sonoplus HD270 homogenizer, Berlin) until the solution became homogenous white. This homogenous tributyrin mix was added to prewarmed $400 \mathrm{ml}$ of LB agar media containing $\mathrm{Km}$ antibiotic, mixed well and poured onto petri plates. P. syringae pv. actinidiae Tn5 mutant colonies randomly picked from plates were spotted one by one on LB agar-tributyrin plates using a toothpick. Plates were further incubated for 3 to 5 days at room temperature in order to see the halo generated due to lipolytic activity. The halo size of $P$. syringae pv. actinidiae $\operatorname{Tn} 5$ mutants was compared with wildtype halo size by visual inspection and the $P$. syringae pv. actinidiae Tn5 mutants that showed any alteration in the level of lipolytic activity were selected for a further round of screening. After three confirmatory rounds of screening $P$. syringae pv. actinidiae Tn 5 mutants with altered lipolytic activity phenotype were selected and grown in liquid LB broth with $\mathrm{Nf}+\mathrm{Km}$, and their glycerol stocks were stored at $-80^{\circ} \mathrm{C}$. All mutants were grown in liquid in LB medium and did not show any significant difference with respect to the wild type.

Localization of Tn5 insertion. In order to clone DNA of $P$. syringae pv. actinidiae adjacent to the transposon insertions, an arbitrary PCR was performed using a pair of primers as previously described in O'Toole and Kolter (1998) with some modifications. Arbitrary PCR products were purified and directly sequenced using Tn5-specific Tn5-Intprimer. Genomic DNA was also isolated from selected $P$. syringae pv. actinidiae Tn5 mutants and double digested either with $B a m \mathrm{HI}+E c o \mathrm{RI}, B a m \mathrm{HI}+S a c \mathrm{I}$, or BamHI $+C l a \mathrm{I}$. These double-digested products were ligated in pBluescript (double digested with the similar set of enzymes), transformed into DH5 $\alpha$ E. coli cells, and selected on $\mathrm{LB}$ agar plates with $\mathrm{Ap}+\mathrm{Km}$. Sequences obtained were subjected to homology searches using NCBI Blast with the draft genome sequence of $P$. syringae pv. actinidiae (str. M302091; taxid:629266). The exact position and orientation of the Tn5 insertions were mapped in $P$. syringae pv. actinidiae draft genome. In order to test if mutants have single Tn5 insertion, the Southern analysis was performed on mutants Lap38, Lap41, Lap45, and Lap 276 using radio labeled Tn5 DNA fragment as a probe. It was confirmed that all these mutants contained a single Tn5 insertion in their chromosome (Supplementary Fig. S1).

Regeneration of knock-out mutants and complementation. The selected Tn5 mutants were regenerated via single homologous recombination using the pKNOCK-Km suicide delivery system. Briefly, internal fragments of the loci were PCR amplified and cloned into a pGEMT-easy vector. EcoRI-digested internal fragments were ligated to EcoRI-digested pKNOCK-Km and transformed into E. coli $\mathrm{C} 118 \lambda$ pir cells yielding pKNOCK plasmids having internal fragments from selected Tn5 loci. These pKNOCK plasmids were then used as a suicide delivery system in a triparental mating as described earlier. The eight mutants (lipolytic altered phenotype [Lap]: Lap38, Lap41, Lap42, Lap45, Lap169, Lap200, Lap208, and Lap276) generated using this strategy were selected on NSA plates supplemented with $\mathrm{Nf}+\mathrm{Km}$. $P$. syringae pv. actinidiae mutant strains were verified by PCR analysis and sequencing.

In order to complement the selected $P$. syringae pv. actinidiae Tn5 mutants, a cosmid library of $P$. syringae pv. actinidiae 10.22 strain was constructed by using the cosmid pLAFR3 (Staskawicz et al. 1987 ) as a vector. Insert DNA was prepared by partial EcoRI digestion of the genomic DNA and then ligated into the corresponding site in pLAFR3. The ligated DNA was then packaged into $\lambda$ phage heads using Gigapack III Gold packaging extract (Stratagene) and the phage particles were transduced to E. coli HB101 as recommended by the supplier. In order to identify the cosmid containing the genes of interest, the cosmid library was screened using the same PCR product as a radiolabeled probe in colony hybridization products that were used to generate $\mathrm{pKNOCK}$ mutants. The required cosmid clones were obtained and were further introduced into respective mutants by triparental conjugation (mutant strain + helper + cosmid containing the expected loci) for complementation analysis. Exconjugants were selected on NSA plates supplemented with Nf, Km, and Tc.

In planta survival and/or growth assay. $P$. syringae pv. actinidiae in planta assay was performed as described previously (Patel et al. 2014). Briefly, 1-year-old potted plants of A. deliciosa 'Hayward' were maintained in a climatic room and watered regularly. For inoculation, $P$. syringae pv. actinidiae strains were grown for $48 \mathrm{~h}$ on NSA medium supplemented with antibiotics at 23 to $25^{\circ} \mathrm{C}$. Bacterial cultures were pelleted, washed with sterile saline $(0.85 \%$ $\mathrm{NaCl}$ in distilled water), and adjusted to 1 to $2 \times 10^{6} \mathrm{CFU} / \mathrm{ml}$ in sterile saline. Leaf areas of approximately $1 \mathrm{~cm}$ in diameter were inoculated using a needleless sterile syringe with the bacterial suspension. For each strain, 10 leaves were inoculated in four sites and control plants were treated in a similar manner using sterile saline. In order to determine the initial in planta bacterial load, leaf disks of about $0.5 \mathrm{~cm}$ diameter were sampled from the inoculation site immediately after infiltration (at $0 \mathrm{~h}$ ) and then ground in $1 \mathrm{ml}$ of sterile saline, and serial 10-fold dilutions were plated onto NSA supplemented with antibiotics. Colonies were counted 2 days after incubation at 23 to $25^{\circ} \mathrm{C}$. CFU/ $0.5 \mathrm{~cm}^{2}$ were then determined for wild type and randomly selected mutant strains as log values and tabulated in order to know the range of initial bacterial load onto the leaves. The fitness in planta over time, the in planta survival and/or growth score of wild type, and all the mutants and their respective complements were then obtained for 3 and 7 days postinoculation (DPI). Confirmation of colony identity was achieved by following well established phenotypic and molecular procedures including duplexPCR (Ferrante and Scortichini 2009, 2010; Gallelli et al. 2011).

\section{RESULTS}

$P$. syringae pv. actinidiae genes involved in lipolytic activity are functionally diverse. It was of interest to determine plate visible phenotypes of $P$. syringae pv. actinidiae that could provide a convenient screen to identify mutants of potential virulence loci. $P$. syringae pv. actinidiae strains were found to exhibit secreted lipase/esterase activity on plate media (Supplementary Fig. S2). It was therefore decided to screen for mutants altered in lipolytic activity with the aim of identifying secretion and global regulatory mutants that are important for $P$. syringae pv. actinidiae virulence. A genome-wide Tn5 mutagenesis and screening experiment for detecting alteration in lipolytic activity was therefore set up in $P$. syringae pv. actinidiae. A Tn5 mutant library of $P$. syringae $\mathrm{pv}$. actinidiae was generated as described in the Materials and Methods section and 30,000 mutants were tested for alteration in lipolytic activity on LB agar-tributyrin plates. In the first round of screening, a total of 254 mutants were obtained with Lap. Some of the Lap mutants were also affected in growth on LB agar-tributyrin plates, suggesting the alteration of the size of the halo might be due to a growth defect; these Lap mutants were not selected for further analysis. All mutants were then further tested for reproducibility of these phenotypes and finally a total of 65 Lap mutants, which were all showing more lipolytic activity than the wild-type strain, were chosen for further study. Surprisingly, in the screen for altered lipolytic activity, no Lap mutants were completely abolished in lipolytic activity (no halo), indicating that probably more than one lipase/esterase enzyme is produced by $P$. syringae pv. actinidiae. In fact, the genome sequence of several $P$. syringae pv. actinidiae strains including $P$. syringae pv. actinidiae ICMP1884 and strain ICMP19096 were found to possess at least three proteins with a lipase domain annotated protein. Based on the zone of clearance (halo) size in LB agar-tributyrin plates, Lap mutants were placed into three different groups from 1 to 3 , in increasing order (Table 2; 
TABLE 2. The details of Tn5 mutants and their in planta survival and/or growth score

\begin{tabular}{|c|c|c|c|c|c|c|c|c|c|c|}
\hline \multirow{2}{*}{$\begin{array}{l}\text { Tn5 } \\
\text { mutants }\end{array}$} & \multirow{2}{*}{$\begin{array}{l}\text { Lipolytic } \\
\text { activity } \\
\text { score }^{\mathrm{b}}\end{array}$} & \multirow{2}{*}{$\begin{array}{c}\operatorname{Tn} 5 \\
\text { insertion }^{2} \\
\text { position }^{\mathrm{c}}\end{array}$} & \multirow{2}{*}{$\begin{array}{c}\text { Orientation } \\
\text { of Tn5 } \\
\text { insertion }^{\text {d }}\end{array}$} & \multirow{2}{*}{$\begin{array}{c}\text { ORF/ } \\
\text { protein } \\
\text { ID of Tn5 } \\
\text { insertion }^{\mathrm{e}}\end{array}$} & \multirow{2}{*}{$\begin{array}{l}\text { ORF } \\
\text { length }\end{array}$} & \multirow[b]{2}{*}{ BlastX information (ORF function) ${ }^{\mathrm{g}}$} & \multirow[b]{2}{*}{ Functional Categorization $^{\mathrm{h}}$} & \multicolumn{2}{|c|}{$\begin{array}{l}\text { In planta survival } \\
\text { and/or growth score }{ }^{\mathrm{i}}\end{array}$} & \multirow{2}{*}{$\begin{array}{l}\text { Virulence } \\
\text { category }\end{array}$} \\
\hline & & & & & & & & 3 days & 7 days & \\
\hline Lap20 & 1 & 2429 & $+/-$ & EGH66838.1 & 2,754 & $\begin{array}{l}\text { Sensor histidine kinase/response } \\
\text { regulator GacS }\end{array}$ & Regulation and signal transduction & $2.43 \mathrm{E}+07$ & $6.00 \mathrm{E}+07$ & $\mathrm{i}$ \\
\hline Lap33 & 1 & 2517 & $+/+$ & EGH66838.1 & 2,754 & $\begin{array}{l}\text { Sensor histidine kinase/response } \\
\text { regulator GacS }\end{array}$ & Regulation and signal transduction & $1.20 \mathrm{E}+07$ & $1.70 \mathrm{E}+07$ & i \\
\hline Lap35 & 1 & 747 & $+1-$ & EGH67056.1 & 837 & Hypothetical protein & Hypothetical & $1.57 \mathrm{E}+07$ & $9.77 \mathrm{E}+07$ & $\mathrm{i}$ \\
\hline Lap36 & 1 & 404 & $+/+$ & EGH64339.1 & 897 & site-specific tyrosine recombinase XerD & Recombination & $1.83 \mathrm{E}+07$ & $2.63 \mathrm{E}+07$ & $\mathrm{i}$ \\
\hline Lap37 & 1 & 354 & $+1-$ & EGH64482.1 & 873 & XerC & Recombination & $3.57 \mathrm{E}+07$ & $2.61 E+07$ & $\mathrm{i}$ \\
\hline Lap38 & 1 & 113 & $+1-$ & EGH67827.1 & 813 & Septum site determining protein $\operatorname{minD}$ & Cell division & $1.46 \mathrm{E}+06$ & $1.68 \mathrm{E}+06$ & ii \\
\hline Lap52 & 1 & 590 & $+1-$ & EGH66838.1 & 2,754 & $\begin{array}{l}\text { Sensor histidine kinase/response } \\
\text { regulator GacS }\end{array}$ & $\begin{array}{l}\text { Regulation and signal } \\
\text { transduction }\end{array}$ & $8.20 \mathrm{E}+07$ & $9.70 \mathrm{E}+07$ & $\mathrm{i}$ \\
\hline Lap54 & 1 & 167 & $+/-$ & EGH67427.1 & 1,113 & Glycosyl transferase & Metabolism & $4.33 \mathrm{E}+06$ & $5.55 \mathrm{E}+06$ & ii \\
\hline Lap55 & 1 & 544 & $+1-$ & EGH65930.1 & 1,788 & Sensory box histidine kinase & $\begin{array}{l}\text { Regulation and signal } \\
\text { transduction }\end{array}$ & $2.37 \mathrm{E}+07$ & $2.40 \mathrm{E}+07$ & $\mathrm{i}$ \\
\hline Lap62 & 1 & 905 & $+/-$ & EGH66807.1 & 2,493 & Helicase domain containing protein & Metabolism & $2.93 \mathrm{E}+07$ & $2.97 \mathrm{E}+07$ & $\mathrm{i}$ \\
\hline Lap71 & 1 & 1048 & $+/+$ & EGH66370.1 & 1,176 & 3-Ketoacyl-CoA thiolase & Metabolism & $2.23 \mathrm{E}+06$ & $2.55 \mathrm{E}+06$ & ii \\
\hline Lap73 & 1 & 278 & $+1-$ & EGH68302.1 & 747 & HAD- superfamily hydrolase & Metabolism & $3.48 \mathrm{E}+06$ & $3.80 \mathrm{E}+06$ & ii \\
\hline Lap81 & 1 & 288 & $+/+$ & EGH65338.1 & 528 & Disulfide bond formation protein DsbB & Metabolism & $3.70 \mathrm{E}+07$ & $3.73 \mathrm{E}+07$ & $\mathrm{i}$ \\
\hline Lap82 & 1 & 502 & $+1-$ & EGH66828.1 & 1,347 & Sensor protein PhoQ & $\begin{array}{l}\text { Regulation and signal } \\
\text { transduction }\end{array}$ & $1.07 \mathrm{E}+07$ & $1.10 \mathrm{E}+07$ & $\mathrm{i}$ \\
\hline Lap83 & 1 & 713 & $+1-$ & EGH66147.1 & 1,938 & Cobaltochelatase subunit CobN & Metabolism & $2.47 \mathrm{E}+07$ & $2.94 \mathrm{E}+07$ & $\mathrm{i}$ \\
\hline Lap84 & 1 & 1200 & t/+ & EPM67430.1 & 1,683 & Helicase, putative & Metabolism & $2.10 \mathrm{E}+07$ & $2.13 \mathrm{E}+07$ & $\mathrm{i}$ \\
\hline Lap106 & 1 & 3 & $+/+$ & EGH67057.1 & 378 & Hypothetical protein & Hypothetical & $1.40 \mathrm{E}+07$ & $1.43 \mathrm{E}+07$ & $\mathrm{i}$ \\
\hline Lap108 & 1 & 401 & $+1-$ & EGH66177.1 & 642 & Hypothetical protein & Hypothetical & $1.14 \mathrm{E}+07$ & $1.31 \mathrm{E}+07$ & $\mathrm{i}$ \\
\hline Lap121 & 1 & 375 & $+1-$ & EGH66177.1 & 642 & Hypothetical protein & Hypothetical & $1.23 \mathrm{E}+07$ & $1.55 \mathrm{E}+07$ & $\mathrm{i}$ \\
\hline Lap131 & 1 & 428 & t/+ & EGH66177.1 & 642 & Hypothetical protein & Hypothetical & $1.03 \mathrm{E}+07$ & $1.07 \mathrm{E}+07$ & $\mathrm{i}$ \\
\hline Lap153 & 1 & 437 & $+/+$ & EGH66177.1 & 642 & Hypothetical protein & Hypothetical & $4.23 \mathrm{E}+07$ & $2.00 \mathrm{E}+07$ & $\mathrm{i}$ \\
\hline Lap161 & 1 & 181 & $+/+$ & EGH65029.1 & 801 & Sec-independent protein translocase TatC & Transport & $8.07 \mathrm{E}+06$ & $8.39 \mathrm{E}+06$ & ii \\
\hline Lap194 & 1 & 283 & $+1-$ & EGH68302.1 & 747 & HAD family hydrolase & Metabolism & $2.17 \mathrm{E}+06$ & $2.49 \mathrm{E}+06$ & ii \\
\hline Lap195 & 1 & 415 & t/+ & EGH64055.1 & 540 & Type IV pilus protein pilI & Motility & $4.67 \mathrm{E}+04$ & $1.96 \mathrm{E}+04$ & iii \\
\hline Lap249 & 1 & 66 & $+/+$ & EGH65067.1 & 825 & $\begin{array}{l}\text { Glycosyl transferase, group } 4 \text { family } \\
\text { protein }\end{array}$ & Metabolism & $7.60 \mathrm{E}+06$ & $7.92 \mathrm{E}+06$ & ii \\
\hline Lap276 & 1 & 422 & $+/-$ & EGH66838.1 & 2,754 & $\begin{array}{l}\text { Sensor histidine kinase/response } \\
\text { regulator GacS }\end{array}$ & $\begin{array}{l}\text { Regulation and signal } \\
\text { transduction }\end{array}$ & $1.27 \mathrm{E}+07$ & $1.30 \mathrm{E}+07$ & $\mathrm{i}$ \\
\hline LapC2 & 1 & 723 & $+1-$ & EPM47746.1 & 1,164 & phosphoglycerate kinase & Metabolism & $2.37 \mathrm{E}+06$ & $2.69 \mathrm{E}+06$ & ii \\
\hline LapC3 & 1 & 288 & $+/+$ & EGH65338.1 & 528 & Disulfide bond formation protein DsbB & Metabolism & $4.50 \mathrm{E}+06$ & $4.82 \mathrm{E}+06$ & ii \\
\hline Lap3 & 2 & 600 & $+1-$ & EGH67743.1 & 888 & Dienelactone hydrolase family protein & Metabolism & $6.67 \mathrm{E}+07$ & $8.73 \mathrm{E}+07$ & $\mathrm{i}$ \\
\hline Lap18 & 2 & 832 & +/+ & EGH65110.1 & 1,119 & Putative lipoprotein & Metabolism & $3.47 \mathrm{E}+07$ & $2.40 \mathrm{E}+07$ & $\mathrm{i}$ \\
\hline Lap34 & 2 & 29 & $+/+$ & EGH65738.1 & 846 & $\begin{array}{l}\text { Glycine/betaine/L-proline } \mathrm{ABC} \\
\text { transporter, }\end{array}$ & Transport & $4.73 \mathrm{E}+06$ & $5.05 \mathrm{E}+06$ & ii \\
\hline Lap39 & 2 & 672 & $+1-$ & EGH65700.1 & 672 & Cell division ATP-binding protein FtsE & Cell division & $1.43 \mathrm{E}+07$ & $1.63 \mathrm{E}+07$ & $\mathrm{i}$ \\
\hline Lap45 & 2 & 208 & $+/+$ & EGH65936.1 & 645 & Thiol:disulfide interchange protein DsbA & Metabolism & $5.23 \mathrm{E}+04$ & $3.72 \mathrm{E}+05$ & iii \\
\hline Lap53 & 2 & 903 & $+/+$ & EGH64518.1 & 1,398 & Phosphomannomutase AlgC & Metabolism & $3.02 \mathrm{E}+05$ & $1.10 \mathrm{E}+05$ & iii \\
\hline Lap60 & 2 & 750 & $+1-$ & EGH64518.1 & 1,398 & Phosphomannomutase AlgC & Metabolism & $5.17 \mathrm{E}+06$ & $5.49 \mathrm{E}+06$ & ii \\
\hline Lap74 & 2 & 2208 & $+1-$ & EGH63578.1 & 2,397 & ATP-dependent protease La & Metabolism & $1.90 \mathrm{E}+07$ & $1.93 \mathrm{E}+07$ & $\mathrm{i}$ \\
\hline Lap76 & 2 & 155 & $+1-$ & EGH64016.1 & 735 & LPS biosynthesis protein & Metabolism & $2.20 \mathrm{E}+07$ & $2.23 \mathrm{E}+07$ & $\mathrm{i}$ \\
\hline Lap78 & 2 & 269 & $+1-$ & EGH64681.1 & 1,620 & Glucan biosynthesis protein D & Metabolism & $2.73 \mathrm{E}+07$ & $2.88 \mathrm{E}+07$ & $\mathrm{i}$ \\
\hline Lap79 & 2 & 475 & $+/+$ & EGH67201.1 & 966 & LacI family transcriptional regulator & Regulation and signal transduction & $5.63 \mathrm{E}+06$ & $7.23 \mathrm{E}+06$ & ii \\
\hline Lap105 & 2 & 861 & t/+ & EGH65701.1 & 1,035 & Cell division protein FtsX & Cell division & $1.13 \mathrm{E}+07$ & $1.19 \mathrm{E}+07$ & $\mathrm{i}$ \\
\hline Lap107 & 2 & 856 & $+/+$ & EGH65701.1 & 1,035 & Cell division protein FtsX & Cell division & $9.33 \mathrm{E}+06$ & $9.65 \mathrm{E}+06$ & $\mathrm{i}^{\mathrm{k}}$ \\
\hline Lap168 & 2 & 1201 & +/+ & EGH64518.1 & 1,398 & Phosphomannomutase $\mathrm{AlgC}$ & Metabolism & $4.67 \mathrm{E}+05$ & $7.87 \mathrm{E}+05$ & iii \\
\hline Lap169 & 2 & 1115 & +/+ & EGH64518.1 & 1,398 & Phosphomannomutase AlgC & Metabolism & $9.00 \mathrm{E}+05$ & $8.84 \mathrm{E}+05$ & iii \\
\hline Lap208 & 2 & 1130 & $+1-$ & EGH65920.1 & 1,590 & Glutamate-cysteine ligase & Metabolism & $3.70 \mathrm{E}+03$ & $4.17 \mathrm{E}+03$ & iii \\
\hline Lap13 & 3 & 674 & $+1-$ & EGH65387.1 & 880 & $\begin{array}{l}\text { Lipid A biosynthesis lauroyl } \\
\text { acyltransferase }\end{array}$ & Metabolism & $1.40 \mathrm{E}+05$ & $1.60 \mathrm{E}+05$ & iii \\
\hline Lap14 & 3 & 166 & $+1-$ & EGH65087.1 & 696 & MotA/TolQ/ExbB proton channel & Transport & $1.40 \mathrm{E}+06$ & $3.30 \mathrm{E}+06$ & ii \\
\hline Lap15 & 3 & 165 & $+1-$ & EGH65087.1 & 696 & MotA/TolQ/ExbB proton channel & Transport & $1.49 \mathrm{E}+06$ & $3.70 \mathrm{E}+06$ & ii \\
\hline Lap16 & 3 & 558 & $+/+$ & EGH65090.1 & 1,302 & Translocation protein TolB & Transport & $1.37 \mathrm{E}+06$ & $2.10 \mathrm{E}+06$ & ii \\
\hline Lap17 & 3 & 515 & $+1-$ & EGH65087.1 & 696 & MotA/TolQ/ExbB proton channel & Transport & $1.39 \mathrm{E}+06$ & $3.80 \mathrm{E}+06$ & ii \\
\hline Lap41 & 3 & 840 & $+/+$ & EGH67601.1 & 1,035 & Outer membrane porin $\mathrm{OprF}$ & Transport & $3.37 \mathrm{E}+06$ & $3.69 \mathrm{E}+06$ & ii \\
\hline Lap42 & 3 & 621 & $+/+$ & EGH65387.1 & 880 & $\begin{array}{l}\text { Lipid A biosynthesis lauroyl } \\
\text { acyltransferase }\end{array}$ & Metabolism & $6.67 \mathrm{E}+04$ & $3.97 \mathrm{E}+04$ & iii \\
\hline Lap61 & 3 & 1092 & $+/+$ & EPM75923.1 & 1,548 & Wbdd & Metabolism & $1.83 \mathrm{E}+07$ & $1.87 \mathrm{E}+07$ & $\mathrm{i}$ \\
\hline Lap77 & 3 & 161 & $+/+$ & EGH67825.1 & 553 & $\begin{array}{l}\text { Lipid A biosynthesis lauroyl } \\
\text { acyltransferase }\end{array}$ & Metabolism & $5.33 \mathrm{E}+06$ & $6.65 \mathrm{E}+06$ & ii \\
\hline Lap176 & 3 & 867 & $+/+$ & EGH65490.1 & 1,305 & Methyl-accepting chemotaxis protein & Chemotaxis & $6.88 \mathrm{E}+06$ & $7.92 \mathrm{E}+06$ & ii \\
\hline Lap188 & 3 & 322 & $+1-$ & EGH67825.1 & 933 & $\begin{array}{l}\text { Lipid A biosynthesis lauroyl } \\
\text { acyltransferase }\end{array}$ & Metabolism & $7.50 \mathrm{E}+06$ & $7.82 \mathrm{E}+06$ & ii \\
\hline Lap200 & 3 & 868 & $+/+$ & EGH65490.1 & 1,305 & Methyl-accepting chemotaxis protein & Chemotaxis & $1.46 \mathrm{E}+05$ & $4.66 \mathrm{E}+05$ & iii \\
\hline
\end{tabular}

${ }^{a}$ Lap: lipolytic altered phenotype.

b Lipolytic activity score of Tn5 mutants on Luria Bertani agar-tributyrin plates (score scale from 1 to 3 ).

${ }^{c}$ position of $\operatorname{Tn} 5$ insertion in the open reading frame (ORF).

d Orientation of Tn5 insertion with respect to ORF.

e Protein ID of ORF in which Tn5 transposon was found inserted.

${ }^{f}$ Length of ORF (in bp) in which Tn5 transposon was found inserted.

g Annotated function of ORF in which Tn5 transposon was found inserted.

${ }^{\text {h }}$ Functional categorization assigned to the functions.

${ }^{\mathrm{i}}$ In planta survival and/or growth score $(\mathrm{CFU} / \mathrm{ml})$ at 3 and 7 days postinoculation (DPI). At $0 \mathrm{~h}$, there was no significant difference in the level of bacterial inoculum $\left(0.5 \mathrm{E}+04\right.$ to $1 \mathrm{E}+04 \mathrm{CFU} / 0.5 \mathrm{~cm}^{2}$ leaf area) for all of the strains tested.

j In planta survival and/or growth category (i: a "wild type" group that displays in planta phenotype similar to the wild type or within a 10-fold difference to wild type $\left[\mathrm{CFU} / 0.5 \mathrm{~cm}^{2}\right.$ leaf area score $1 \mathrm{E}+07$ and above either at 3 or $\left.7 \mathrm{DPI}\right]$; ii: a fitness in planta deficient group displaying a 10- to 100-fold difference [CFU/0.5 $\mathrm{cm}^{2}$ score less than $1 \mathrm{E}+07$ and higher than $1 \mathrm{E}+06$ either at 3 or $\left.7 \mathrm{DPI}\right]$; and iii: a severely fitness in planta deficient group displaying more than 100 -fold difference compared with wild type [CFU/0.5 $\mathrm{cm}^{2}$ leaf area score $1 \mathrm{E}+06$ or less either at 3 or $\left.7 \mathrm{DPI}\right]$ ).

${ }^{\mathrm{k}}$ Score is close to category i. 
Fig. 1). Out of a total of 56 mutants in which the position of the Tn5 insertion could be localized (see below), 27 Lap mutants were classified into group 1, 17 Lap mutants were group 2, and 12 Lap mutants were group 3 .

The position of Tn5 insertion sites was determined using an arbitrary PCR method as described in the Materials and Methods section; this was successful for 56 of 65 Lap mutants (Table 2). For the remaining nine Lap mutants, a molecular cloning approach was used without success as described in the Materials and Methods. The reason for this is not known and it is most likely that the methodology used had limitations that are currently unknown. The 56 Lap mutants were localized to 38 different ORFs (several Lap mutants were isolated more than once) belonging to eight different functional categories: cell division, chemotaxis, hypothetical proteins, metabolism, motility, recombination, regulation, and signal transduction and transport (Table 2; Fig. 2; Supplementary Fig. S3). Mutations in genes encoding for lipid A biosynthesis, MotA/TolQ/ExbB and TolB mediated transport, chemotaxis and porin OprF caused a drastic increase (group 3) in lipolytic activity, whereas mutation in genes encoding cell division proteins Fts X and FtsE, putative hydrolases, redox homeostasis functions like GshA, DsbA, and DsbB, phosphomannomutase AlgC, putative lipoprotein, ATP-dependent protease La, Glucan biosynthesis protein D, LacI family transcriptional regulator, and glycine/betaine/ L-proline $\mathrm{ABC}$ transporter caused a moderate increase (group 2) in lipolytic activity. Mutations in the remaining genes including genes coding for metabolic and regulatory functions caused a slight and consistent increase (group 1) in lipolytic activity (Table 2).

Several of Lap mutants are affected in growth or survival in planta. It was of interest to assess the possible role of identified $P$. syringae pv. actinidiae Tn5 mutants in survival and/ or growth in kiwifruit leaves. All of the P. syringae pv. actinidiae

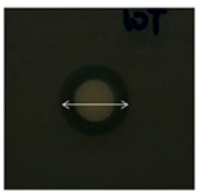

WT

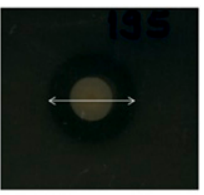

1

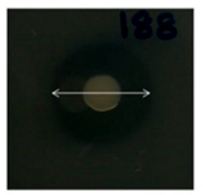

2

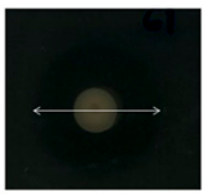

3
Fig. 1. Lipolytic activity score. Lipolytic activity is visible as clearance zone (halo) on the Luria Bertani (LB) agar-tributyrin plate. The zone of clearance of wild-type Pseudomonas syringae pv. actinidiae was used as a standard or no change in the level of lipolytic activity. Compared with the wild-type (WT) level, the increasing size of the zone of clearance on LB agar-tributyrin plate, lipolytic activity score was categorized from 1 to 3 . A score of 3 indicates a maximum level of increase in the zone of clearance (lipolytic activity).
Lap mutants were inoculated on A. deliciosa kiwifruit leaves and bacterial colonization was determined at $0 \mathrm{~h}$ and after 3 and 7 DPI by bacterial count $\left(\mathrm{CFU} / 0.5 \mathrm{~cm}^{2}\right)$. At $0 \mathrm{~h}$, there was no significant difference in the level of bacterial inoculum $\left(0.5-1 \mathrm{E}+04 \mathrm{CFU} / 0.5 \mathrm{~cm}^{2}\right)$ for all of the strains tested. The analysis of three rounds of experiments revealed that several $P$. syringae pv. actinidiae mutants were significantly impaired in in planta survival and/or growth compared with wild-type $P$. syringae pv. actinidiae at 3 and 7 DPI (Table 2). We assigned three different in planta survival and/or growth score categories to the mutants: (i) a "wild type" group that display in planta survival and/or growth phenotype similar to the wild type or within a 10 -fold difference (CFU/ $0.5 \mathrm{~cm}^{2}$ score $1 \mathrm{E}+07$ and above either at 3 or 7 DPI), (ii) a fitness in planta deficient group displaying a 10- to 100fold difference (CFU/0.5 cm $\mathrm{cm}^{2}$ score less than $1 \mathrm{E}+07$ and higher than $1 \mathrm{E}+06$ either at 3 or $7 \mathrm{DPI}$ ), and (iii) in planta severely fitness deficient group displaying more than 100-fold difference compared with wild type (CFU/0.5 $\mathrm{cm}^{2}$ score $1 \mathrm{E}+06$ or less either at 3 or $\left.7 \mathrm{DPI}\right)$. Out of the 56 mutants total in which the disrupted gene could be localized, 27, 20, and 9 Lap mutants were placed into categories i, ii, and iii, respectively. In general, some metabolic functions were found to be associated with reduced growth or survival in planta. The mutants affected in genes encoding for transporters and cell division belonged to the middle category, whereas the mutants in the two-component regulatory genes displayed in most cases a phenotype similar to the wild type. A few mutants displayed a more significant difference in survival and/or growth in the kiwifruit leaves including loci involved in motility and metabolism (Table 2).

Validation of the results by regeneration of the mutants and their complementation. In order to validate the results, genes affected in some of the transposon mutants were regenerated by homologous recombination. The in planta fitness and lipolytic activity phenotypes of these mutants and the complemented strains were then verified. Mutations were generated in genes identified in the eight out of nine Tn 5 mutants drastically affected in fitness in planta as described in the Materials and Methods section. Importantly, all the eight regenerated knock-out mutants were found to display similar phenotypic behavior as the Tn 5 mutants isolated in the screen. These results validated the screen indicating that the genetic locus in which the Tn5 was inserted was responsible for the observed phenotype (Fig. 3). Four of these mutants originally isolated from the Tn5 genomic mutant library were also tested for the presence of a single Tn5 insertion in the chromosome; the four mutants had one Tn5 in their genome. Of the eight mutants complemented with a cosmid clone, five displayed complementation for plate phenotype while three also showed partial restoration of in planta phenotype (Supplementary Table S3). The lack of
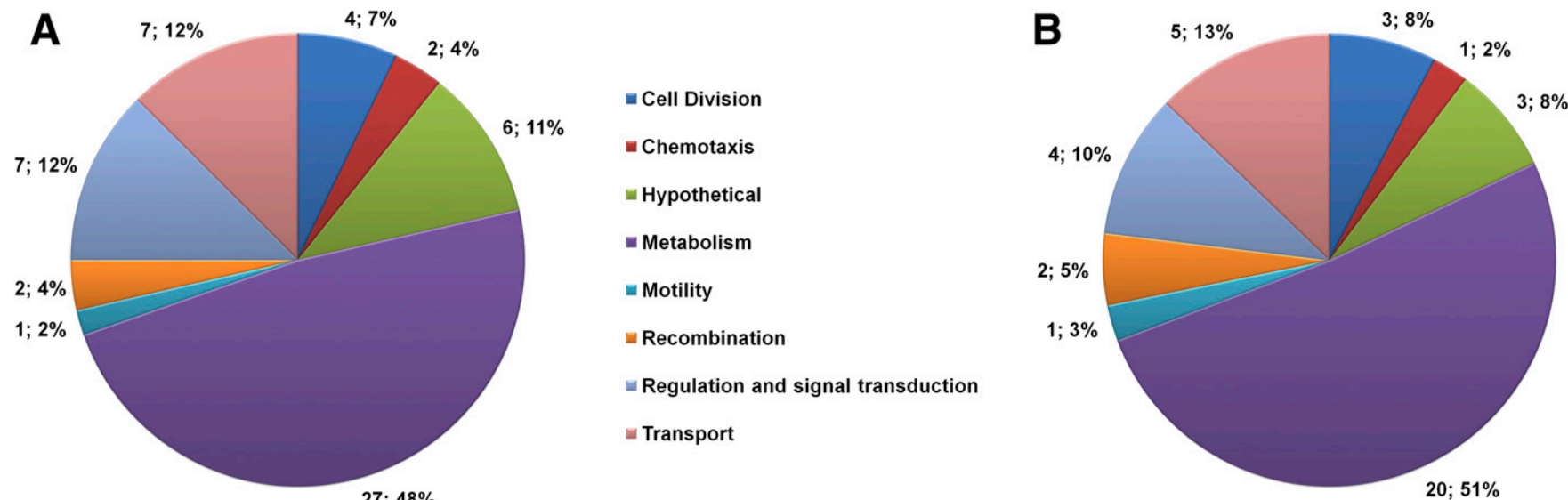

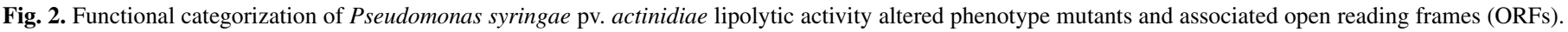

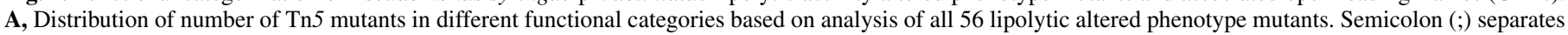

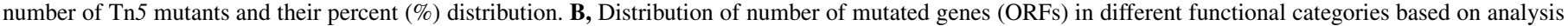
of all 38 ORFs in lipolytic activity altered phenotype screening. Semicolon (;) separates number of ORFs and their percent (\%) distribution. 
complementation in some of these mutants could be due to the cosmid clone not containing all the genetic material necessary for the complementation. Another possibility could be due to multicopy allele effects of these genes that may cause instability or fitness cost. In planta complementation could have also failed due to an instability of the plasmid since there is no in planta selection.

\section{DISCUSSION}

Despite the importance of $P$. syringae pv. actinidiae as an emerging phytopathogen of kiwifruit plants worldwide, to date no major genetic studies have been performed to understand its virulence functions. The aim of this study was to begin to study the genetic and molecular mechanisms employed by $P$. syringae $\mathrm{pv}$. actinidiae to colonize the kiwifruit plant. The approach used was selection via a genetic screen of $30,000 \mathrm{Tn} 5$ mutants for alteration in lipolytic activity phenotype; this resulted in the identification of 56 Tn5 mutants. Lipase secretion in Pseudomonas group of bacteria is known to be mediated by either type I or type II secretion systems (Rosenau and Jaeger 2000). We expected to find mutations in genes associated with these secretion systems with lipolytic minus phenotype in the screen. Although we found a few mutants with reduced lipolytic activity compared with the wild-type strain, these were also affected in growth. It was therefore postulated that the reduced lipolytic activity could have been due to a defect in growth and therefore we did not select them in this study. In the screen, none of them were completely abolished for lipolytic activity. This suggested that either we did not find a mutation in protein secretion system genes or $P$. syringae pv. actinidiae has different protein secretion systems for different lipases and mutation in any one of them did not result in lipolytic minus phenotype.

Lipolytic enzyme LipA is an important virulence factor in several phytopathogens including Xanthomonas oryzae pv. oryzae (Aparna et al. 2009; Jha et al. 2007), X. campestris pv. vesicatoria (TamirAriel et al. 2012), Burkholderia glumae (Devescovi et al. 2007) as well as the contribution of lipolytic enzymes to virulence of fungal pathogens like Alternaria brassicicola (Berto et al. 1999), Blumeria graminis (Feng et al. 2009), and Fusarium spp. (Bravo-Ruiz et al. 2013; Voigt et al. 2005). Production of secreted enzymes usually employs global loci involved in virulence. In line with this, our screen identified 38 genes coding for metabolic, transport, and regulatory functions involved in modulation of lipolytic activity; many of these genes affected in planta survival or growth of $P$. syringae pv. actinidiae. How these genes modulate the lipolytic activity or $P$. syringae pv. actinidiae in planta growth/survival needs to be understood.

Lipase (triacylglycerol acylhydrolase, EC. 3.1.1.3) is an important class of enzymes that hydrolyze the carboxyl ester bonds in mono, di-, and triglycerides to liberate fatty acids and alcohols; they have been studied mostly for biotechnological applications. Very few genetic studies have been reported for production and regulation of lipase/ esterase. One of these has shown the involvement of quorum sensing in Burkholderia glumae (Devescovi et al. 2007). In this study, several genes involved in regulation of lipolytic activity phenotype of $P$. syringae pv. actinidiae were identified and their possible role in
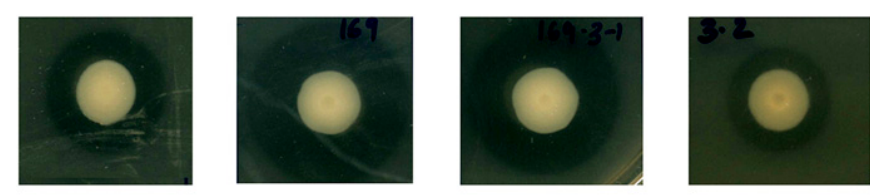

WT A lipase biosynthesis/production/secretion is discussed here. Lap mutants with the mutation in genes coding for transport associated functions such as TolB and TolQ and lipopolysaccharide associated functions (LPS biosynthesis protein, lipid A biosynthesis lauroyl acyltransferase, AlgC, WbdD) showed markedly increased levels of lipolytic activity in our screen compared with other Lap mutants. These genes are known to be directly or indirectly involved in bacterial membrane integrity (Nikaido 2003).

Different from the transport and LPS biosynthesis genes, Lap mutants in genes coding for cell division associated FtsE and FtsX, DsbA, and DsbB, and a putative dienelactone hydrolase appear to affect lipolytic activity in $P$. syringae pv. actinidiae to a lesser extent. In previous studies, fts $X, f t s E$, and $f t s X$ of Aeromonas spp. have been implicated in chitinase production and transport functions (Ahmadian et al. 2007; de Leeuw et al. 1999). DsbA and DsbB are disulfide bond introducing proteins that are known to promote the oxidative folding of secreted proteins (Inaba 2009). DsbA and DsbC have been shown to affect extracellular enzyme formation in $P$. aeruginosa; the $d s b A$ mutant was defective for lipase production whereas mutation in $d s b C$ increased the secretion of lipase by twofold (Urban et al. 2001). A new esterase characterized in a strict Vibrio sp. marine bacterium (Park et al. 2007) showed primary structure similarity to a putative dienelactone hydrolase of $P$. syringae pv. actinidiae suggesting that this protein might have esterase/lipase activity. It is possible that due to a mutation in the gene coding for this lipase, $P$. syringae pv. actinidiae compensates by over production of other lipase/esterase(s).

Lastly, $P$. syringae pv. actinidiae Lap mutants affected in regulatory functions including two component regulators such as GacS and PhoQ showed the least increase in lipolytic activity. The global twocomponent system $\mathrm{GacA} / \mathrm{GacS}$ responds to a yet unknown signal (could be endogenously produced) and regulates many phenotypes including quorum sensing systems in pseudomonads (Aparna et al. 2009; Reimmann et al. 1997). Elevated accumulation of the PhoP response regulator on the other hand, has been reported in a lipC mutant of $P$. aeruginosa (Rosenau et al. 2010). This suggests that PhoP could be a negative regulator of lipolytic activity as a mutation in PhoP results in increased lipolytic activity in $P$. syringae pv. actinidiae. It cannot be excluded that phosphate levels regulate lipolytic activity in $P$. syringae pv. actinidiae.

The Lap mutants that are affected in fitness in planta were found mutated for functions mainly in loci encoding for glutamatecysteine ligase (group iii Lap mutant), methyl-accepting chemotaxis protein (group ii and iii Lap mutant), lipid A biosynthesis lauroyl acyltransferase (group iii Lap mutant), phosphomannomutase $\operatorname{AlgC}$ (group ii and iii lap mutant), thiol:disulfide interchange protein DsbA (group ii Lap mutants), type IV pilus protein PilI (group iii Lap mutant), Tol operon (group ii Lap mutant), HAD family hydrolase (group i and ii Lap mutants), and outer membrane porin OprF (group ii Lap mutant). The possible roles in fitness in planta of these loci is discussed below.

Glutamate-cysteine ligase catalyzes the first and rate limiting step in the biosynthesis of glutathione (Meister and Anderson 1983). Glutathione acts as the central redox buffer system and plays a major role in cellular homeostasis against various oxidative stresses (Meister and Anderson 1983). Therefore, the glutamatecysteine ligase Lap mutant in $P$. syringae pv. actinidiae could be affected in survival/colonization under adverse/stress conditions in planta. Another function involved in redox homeostasis is $d s b A$ which has been shown to be important for expression of the type III secretion system, intracellular survival and twitching motility (Ha et al. 2003). Thus, the virulence deficiency of $P$. syringae pv. actinidiae $d s b A$ mutant could also possibly be due to its effect on type III effector proteins.

Functions involved in chemotaxis and twitching motility were also affected in fitness in planta. Methyl-accepting chemotaxis proteins are important for bacterial movement, biofilm formation, virulence, and competitive fitness in several bacteria (Ferrandez

Fig. 3. Lipolytic activity phenotype of phosphomannomutase AlgC mutant and complemented strain on Luria Bertani agar-tributyrin plate. Lipolytic activity is visible as clearance zone (halo) from WT, wild type; A, Tn5phosphomannomutase AlgC mutant; B, pKnock-phosphomannomutase AlgC mutant; and $\mathrm{C}$, complemented strain of phosphomannomutase AlgC mutant. 
et al. 2002; Garvis et al. 2009; McLaughlin et al. 2012; Yao and Allen 2006). On the other hand, the type IV pili is required for host colonization and adherence, biofilm formation, antimicrobial tolerance, and pathogenicity functions (Roine et al. 1998; Romantschuk and Bamford 1986; Suoniemi et al. 1995; Taguchi and Ichinose 2011) and thus the Pill mutant of $P$. syringae pv. actinidiae might be affected in in planta survival and/or growth due to one or more of these reasons. The phosphomannomutase $\mathrm{AlgC}$ in P. aeruginosa is involved in the synthesis of alginate (a type of exopolysaccharide [EPS]) and LPS (Ye et al. 1994). EPS provides a selective advantage to bacteria in multiple ways, including water absorption, minerals and nutrients accumulation, protection from hydrophobic and toxic macromolecules (Denny 1995), biofilm formation, and virulence in several phytopathogenic bacteria, including $P$. syringae (Fett and Dunn 1989; Yu et al. 1999), Ralstonia (Pseudomonas) solanacearum (Kao et al. 1992; Saile et al. 1997), Erwinia stewartii (Dolph et al. 1988), and $X$. campestris (Katzen et al. 1998). Therefore, mutation in $a \lg C$ homolog of $P$. syringae pv. actinidiae might affect virulence due to loss of any of these functions.

Among the transport functions, outer membrane porin OprF is a multifunctional porin involved in nonspecific diffusion of ionic molecules and small polar nutrients, including the polysaccharides (Nestorovich et al. 2006). OprF might affect virulence due to its role in transport or adhesion to host (Azghani et al. 2002) and biofilm formation (Yoon et al. 2002). TolQ and TolB functions are part of the Tol-Pal (peptidoglycan-associated lipoprotein) system that form a membrane-spanning multiprotein complex. The Tol-Pal complexes have been associated with several functions including role in transport, membrane integrity, and virulence (Godlewska et al. 2009). In soft rot causing pathogen Erwinia chrysanthemi, TolB, TolQ, and other Tol function mutants were found to be affected in growth under stress conditions, in cell morphology, in motility, and in virulence (Dubuisson et al. 2005). Therefore, the transport and/or membrane integrity functions of the Tol system are important for $P$. syringae pv. actinidiae fitness in planta.

In summary, in this study several loci employed in the biosynthesis/ modulation of lipolytic activity have been unraveled, several of which are involved in the colonization of kiwifruit. Our genetic approach taking advantage of a secreted visible phenotype will be useful to identify virulence/colonization functions of other bacteria. Further studies on these genes are required to begin to understand the molecular mechanisms underlying $P$. syringae pv. actinidiae pathogenesis process.

\section{ACKNOWLEDGMENTS}

H. Kumar Patel was funded by an ICGEB fellowship and M. Xianfa by a fellowship of the CSC (China). We thank I. Bertani and G. Devescovi for their interest and technical assistance, and R. W. Jackson (University of Reading, U.K.) for his constant input and interest.

\section{LITERATURE CITED}

Abelleira, A., López, M. M., Peñalver, J., Aguín, O., Mansilla, J. P., Picoaga, A., and García, M. J. 2011. First report of bacterial canker of kiwifruit caused by Pseudomonas syringae pv. actinidiae in Spain. Plant Dis. 95:1583.

Ahmadian, G., Degrassi, G., Venturi, V., Zeigler, D. R., Soudi, M., and Zanguinejad, P. 2007. Bacillus pumilus SG2 isolated from saline conditions produces and secretes two chitinases. J. Appl. Microbiol. 103:1081-1089.

Anonymous. 2011. Bacterial canker, kiwifruit-Chile: First report (O'Higgins, Maule). ProMED mail. International Society For Infectious Disease.

Aparna, G., Chatterjee, A., Sonti, R. V., and Sankaranarayanan, R. 2009. A cell wall-degrading esterase of Xanthomonas oryzae requires a unique substrate recognition module for pathogenesis on rice. Plant Cell 21: $1860-1873$.

Azghani, A. O., Idell, S., Bains, M., and Hancock, R. E. 2002. Pseudomonas aeruginosa outer membrane protein $\mathrm{F}$ is an adhesin in bacterial binding to lung epithelial cells in culture. Microbiol. Pathog. 33:109-114.

Balestra, G. M., Renzi, M., and Mazzaglia, A. 2010. First report on bacterial canker of Actinidia deliciosa caused by Pseudomonas syringae pv. actinidiae in Portugal. New Dis. Rep. 22:10.
Bastas, K. K., and Karakaya, A. 2012. First report of bacterial canker of kiwifruit caused by Pseudomonas syringae pv. actinidiae in Turkey. Plant Dis. 96:452.

Berto, P., Commenil, P., Belingheri, L., and Dehorter, B. 1999. Occurrence of a lipase in spores of Alternaria brassicicola with a crucial role in the infection of cauliflower leaves. FEMS Microbiol. Lett. 180:183-189.

Better, M., Lewis, B., Corbin, D., Ditta, G., and Helinski, D. R. 1983. Structural relationships among Rhizobium meliloti symbiotic promoters. Cell 35:479-485.

Birnboim, H. C. 1983. A rapid alkaline extraction method for the isolation of plasmid DNA. Methods Enzymol. 100:243-255.

Bravo-Ruiz, G., Ruiz-Roldan, C., and Roncero, M. I. 2013. Lipolytic system of the tomato pathogen Fusarium oxysporum f. sp. lycopersici. Mol. PlantMicrobe Interact. 26:1054-1067.

Butler, M. I., Stockwell, P. A., Black, M. A., Day, R. C., Lamont, I. L., and Poulter, R. T. 2013. Pseudomonas syringae pv. actinidiae from recent outbreaks of kiwifruit bacterial canker belong to different clones that originated in China. PLoS ONE 8:e57464.

Buttner, D., and Bonas, U. 2010. Regulation and secretion of Xanthomonas virulence factors. FEMS Microbiol. Rev. 34:107-133.

Cameron, A., Zoysa, G. H., and Sarojini, V. 2014. Antimicrobial peptides against Pseudomonas syringae pv. actinidiae and Erwinia amylovora: Chemical synthesis, secondary structure, efficacy, and mechanistic investigations. Biopolymers 102:88-96.

Cellini, A., Fiorentini, L., Buriani, G., Yu, J., Donati, I., Cornish, D. A., Novak, B., Costa, G., Vanneste, J. L., and Spinelli, F. 2014. Elicitors of the salicylic acid pathway reduce incidence of bacterial canker of kiwifruit caused by Pseudomonas syringae pv. actinidiae. Ann. Appl. Biol. 165:441-453.

Chang, J. H., Desveaux, D., and Creason, A. L. 2014. The ABCs and 123s of bacterial secretion systems in plant pathogenesis. Annu. Rev. Phytopathol. 52:317-345.

Chapman, J. R., Taylor, R. K., Weir, B. S., Romberg, M. K., Vanneste, J. L., Luck, J., and Alexander, B. J. 2012. Phylogenetic relationships among global populations of Pseudomonas syringae pv. actinidiae. Phytopathology 102:1034-1044.

Ciarroni, S., Gallipoli, L., Taratufolo, M. C., Butler, M. I., Poulter, R. T., Pourcel, C., Vergnaud, G., Balestra, G. M., and Mazzaglia, A. 2015. Development of a multiple loci variable number of tandem repeats analysis (MLVA) to unravel the intra-pathovar structure of Pseudomonas syringae pv. actinidiae populations worldwide. PLoS ONE 10:e0135310.

Cunty, A., Cesbron, S., Poliakoff, F., Jacques, M. A., and Manceau, C. 2015. Origin of the outbreak in France of Pseudomonas syringae pv. actinidiae biovar 3, the causal agent of bacterial canker of kiwifruit, revealed by a multilocus variable-number tandem-repeat analysis. Appl. Environ. Microbiol. 81:6773-6789.

de Leeuw, E., Graham, B., Phillips, G. J., ten Hagen-Jongman, C. M., Oudega, B., and Luirink, J. 1999. Molecular characterization of Escherichia coli FtsE and FtsX. Mol. Microbiol. 31:983-993.

Denny, T. P. 1995. Involvement of bacterial polysaccharides in plant pathogenesis. Annu. Rev. Phytopathol. 33:173-197.

Devescovi, G., Bigirimana, J., Degrassi, G., Cabrio, L., LiPuma, J. J., Kim, J., Hwang, I., and Venturi, V. 2007. Involvement of a quorum-sensingregulated lipase secreted by a clinical isolate of Burkholderia glumae in severe disease symptoms in rice. Appl. Environ. Microbiol. 73:4950-4958.

Di Lallo, G., Evangelisti, M., Mancuso, F., Ferrante, P., Marcelletti, S., Tinari, A., Superti, F., Migliore, L., D'Addabbo, P., Frezza, D., Scortichini, M., and Thaller, M. C. 2014. Isolation and partial characterization of bacteriophages infecting Pseudomonas syringae pv. actinidiae, causal agent of kiwifruit bacterial canker. J. Basic Microbiol. 54:1210-1221.

Dolph, P. J., Majerczak, D. R., and Coplin, D. L. 1988. Characterization of a gene cluster for exopolysaccharide biosynthesis and virulence in Erwinia stewartii. J. Bacteriol. 170:865-871.

Dubuisson, J. F., Vianney, A., Hugouvieux-Cotte-Pattat, N., and Lazzaroni, J. C. 2005. Tol-Pal proteins are critical cell envelope components of Erwinia chrysanthemi affecting cell morphology and virulence. Microbiology 151:3337-3347.

Everett, K., Taylor, R., Romberg, M., Rees-George, J., Fullerton, R., Vanneste, J., and Manning, M. 2011. First report of Pseudomonas syringae pv. actinidiae causing kiwifruit bacterial canker in New Zealand. Australas. Plant Dis. 6:67-71.

Feng, J., Wang, F., Liu, G., Greenshields, D., Shen, W., Kaminskyj, S., Hughes, G. R., Peng, Y., Selvaraj, G., Zou, J., and Wei, Y. 2009. Analysis of a Blumeria graminis-secreted lipase reveals the importance of host epicuticular wax components for fungal adhesion and development. Mol. PlantMicrobe Interact. 22:1601-1610.

Ferrandez, A., Hawkins, A. C., Summerfield, D. T., and Harwood, C. S. 2002. Cluster II che genes from Pseudomonas aeruginosa are required for an optimal chemotactic response. J. Bacteriol. 184:4374-4383.

Ferrante, P., and Scortichini, M. 2009. Identification of Pseudomonas syringae pv. actinidiae as causal agent of bacterial canker of yellow kiwifruit (Actinidia chinensis Planchon) in central Italy. J. Phytopathol. 157:768-770. 
Ferrante, P., and Scortichini, M. 2010. Molecular and phenotypic features of Pseudomonas syringae pv. actinidiae isolated during recent epidemics of bacterial canker on yellow kiwifruit (Actinidia chinensis) in central Italy. Plant Pathol. 59:954-962.

Fett, W. F., and Dunn, M. F. 1989. Exopolysaccharides produced by phytopathogenic Pseudomonas syringae pathovars in infected leaves of susceptible hosts. Plant Physiol. 89:5-9.

Figurski, D. H., and Helinski, D. R. 1979. Replication of an origin-containing derivative of plasmid RK2 dependent on a plasmid function provided in trans. Proc. Natl. Acad. Sci. USA 76:1648-1652.

Fujikawa, T., and Sawada, H. 2016. Genome analysis of the kiwifruit canker pathogen Pseudomonas syringae pv. actinidiae biovar 5. Sci. Rep. 6:21399.

Gallelli, A., L'Aurora, A., and Loreti, S. 2011. Gene sequence analysis for the molecular detection of Pseudomonas syringae pv. actinidiae: Developing diagnostic protocols. J. Plant Pathol. 93:425-435.

Gardan, L., Shafik, H., Belouin, S., Broch, R., Grimont, F., and Grimont, P. A. 1999. DNA relatedness among the pathovars of Pseudomonas syringae and description of Pseudomonas tremae sp. nov. and Pseudomonas cannabina sp. nov. (ex Sutic and Dowson 1959). Int. J. Syst. Bacteriol. 49:469-478.

Garvis, S., Munder, A., Ball, G., de Bentzmann, S., Wiehlmann, L., Ewbank, J. J., Tummler, B., and Filloux, A. 2009. Caenorhabditis elegans semi-automated liquid screen reveals a specialized role for the chemotaxis gene cheB2 in Pseudomonas aeruginosa virulence. PLoS Pathog. 5:e1000540.

Ghods, S., Sims, I. M., Moradali, M. F., and Rehm, B. H. 2015. Bactericidal compounds controlling growth of the plant pathogen Pseudomonas syringae pv. actinidiae, which forms biofilms composed of a novel exopolysaccharide. Appl. Environ. Microbiol. 81:4026-4036.

Godlewska, R., Wisniewska, K., Pietras, Z., and Jagusztyn-Krynicka, E. K. 2009. Peptidoglycan-associated lipoprotein (Pal) of Gram-negative bacteria: Function, structure, role in pathogenesis and potential application in immunoprophylaxis. FEMS Microbiol. Lett. 298:1-11.

Grant, S. G., Jessee, J., Bloom, F. R., and Hanahan, D. 1990. Differential plasmid rescue from transgenic mouse DNAs into Escherichia coli methylation-restriction mutants. Proc. Natl. Acad. Sci. USA 87:4645-4649.

Ha, U. H., Wang, Y., and Jin, S. 2003. DsbA of Pseudomonas aeruginosa is essential for multiple virulence factors. Infect. Immun. 71:1590-1595.

Hauser, A. R. 2009. The type III secretion system of Pseudomonas aeruginosa: Infection by injection. Nat. Rev. Microbiol. 7:654-665.

Herrero, M., de Lorenzo, V., and Timmis, K. N. 1990. Transposon vectors containing non-antibiotic resistance selection markers for cloning and stable chromosomal insertion of foreign genes in Gram-negative bacteria. J. Bacteriol. 172:6557-6567.

Hirano, S. S., and Upper, C. D. 2000. Bacteria in the leaf ecosystem with emphasis on Pseudomonas syringae a pathogen, ice nucleus, and epiphyte. Microbiol. Mol. Biol. Rev. 64:624-653.

Inaba, K. 2009. Disulfide bond formation system in Escherichia coli. J. Biochem. 146:591-597.

Jha, G., Rajeshwari, R., and Sonti, R. V. 2007. Functional interplay between two Xanthomonas oryzae pv. oryzae secretion systems in modulating virulence on rice. Mol. Plant-Microbe Interact. 20:31-40.

Joardar, V., Lindeberg, M., Jackson, R. W., Selengut, J., Dodson, R., Brinkac, L. M., Daugherty, S. C., Deboy, R., Durkin, A. S., Giglio, M. G., Madupu, R., Nelson, W. C., Rosovitz, M. J., Sullivan, S., Crabtree, J., Creasy, T., Davidsen, T., Haft, D. H., Zafar, N., Zhou, L., Halpin, R., Holley, T., Khouri, H., Feldblyum, T., White, O., Fraser, C. M., Chatterjee, A. K., Cartinhour, S., Schneider, D. J., Mansfield, J., Collmer, A., and Buell, C. R. 2005. Whole-genome sequence analysis of Pseudomonas syringae pv. phaseolicola 1448A reveals divergence among pathovars in genes involved in virulence and transposition. J. Bacteriol. 187:6488-6498.

Kao, C. C., Barlow, E., and Sequeira, L. 1992. Extracellular polysaccharide is required for wild-type virulence of Pseudomonas solanacearum. J. Bacteriol. 174:1068-1071.

Katzen, F., Ferreiro, D. U., Oddo, C. G., Ielmini, M. V., Becker, A., Puhler, A., and Ielpi, L. 1998. Xanthomonas campestris pv. campestris gum mutants: Effects on xanthan biosynthesis and plant virulence. J. Bacteriol. 180:1607-1617.

King, E. O., Ward, M. K., and Raney, D. E. 1954. Two simple media for the demonstration of pyocyanin and fluorescin. J. Lab. Clin. Med. 44:301-307.

Koh, Y. J., and Nou, I. S. 2002. DNA markers for identification of Pseudomonas syringae pv. actinidiae. Mol. Cells 13:309-314.

Koh, Y. J., Cha, B. J., Chung, H. J., and Lee, D. H. 1994. Outbreak and spread of bacterial canker of kiwifruit. Korean J. Plant Pathol. 10:68-72.

Koh, H. S., Kim, G. H., Lee, Y. S., Koh, Y. J., and Jung, J. S. 2014. Molecular characteristics of Pseudomonas syringae pv. actinidiae strains isolated in Korea and a multiplex PCR Assay for haplotype differentiation. Plant Pathol. J. 30:96-101.

Laue, H., Schenk, A., Li, H., Lambertsen, L., Neu, T. R., Molin, S., and Ullrich, M. S. 2006. Contribution of alginate and levan production to biofilm formation by Pseudomonas syringae. Microbiology 152:2909-2918.

Lee, Y. S., Kim, G. H., Koh, Y. J., Zhuang, Q., and Jung, J. S. 2016. Development of specific markers for identification of biovars 1 and 2 strains of Pseudomonas syringae pv. actinidiae. Plant Pathol. J. 32:162-167.
Lindeberg, M., Myers, C. R., Collmer, A., and Schneider, D. J. 2008. Roadmap to new virulence determinants in Pseudomonas syringae: Insights from comparative genomics and genome organization. Mol. Plant-Microbe Interact. 21:685-700.

Marcelletti, S., and Scortichini, M. 2014. Definition of plant-pathogenic Pseudomonas genomospecies of the Pseudomonas syringae complex through multiple comparative approaches. Phytopathology 104:1274-1282.

Marcelletti, S., Ferrante, P., Petriccione, M., Firrao, G., and Scortichini, M. 2011. Pseudomonas syringae pv. actinidiae draft genomes comparison reveal strain-specific features involved in adaptation and virulence to Actinidia species. PLoS ONE 6:e27297.

Mazzaglia, A., Studholme, D. J., Taratufolo, M. C., Cai, R., Almeida, N. F., Goodman, T., Guttman, D. S., Vinatzer, B. A., and Balestra, G. M. 2012. Pseudomonas syringae pv. actinidiae (PSA) isolates from recent bacterial canker of kiwifruit outbreaks belong to the same genetic lineage. PLoS ONE 7:e36518.

McCann, H. C., Rikkerink, E. H., Bertels, F., Fiers, M., Lu, A., Rees-George, J., Andersen, M. T., Gleave, A. P., Haubold, B., Wohlers, M. W., Guttman, D. S., Wang, P. W., Straub, C., Vanneste, J. L., Rainey, P. B., and Templeton, M. D. 2013. Genomic analysis of the kiwifruit pathogen Pseudomonas syringae pv. actinidiae provides insight into the origins of an emergent plant disease. PLoS Pathog. 9:e1003503.

McLaughlin, H. P., Caly, D. L., McCarthy, Y., Ryan, R. P., and Dow, J. M. 2012. An orphan chemotaxis sensor regulates virulence and antibiotic tolerance in the human pathogen Pseudomonas aeruginosa. PLoS One 7:e42205.

Meister, A., and Anderson, M. E. 1983. Glutathione. Annu. Rev. Biochem. 52: 711-760.

Nestorovich, E. M., Sugawara, E., Nikaido, H., and Bezrukov, S. M. 2006. Pseudomonas aeruginosa porin OprF: Properties of the channel. J. Biol. Chem. 281:16230-16237.

Nikaido, H. 2003. Molecular basis of bacterial outer membrane permeability revisited. Microbiol. Mol. Biol. Rev. 67:593-656.

O'Toole, G. A., and Kolter, R. 1998. Initiation of biofilm formation in Pseudomonas fluorescens WCS365 proceeds via multiple, convergent signaling pathways: A genetic analysis. Mol. Microbiol. 28:449-461.

Park, S. Y., Kim, J. T., Kang, S. G., Woo, J. H., Lee, J. H., Choi, H. T., and Kim, S. J. 2007. A new esterase showing similarity to putative dienelactone hydrolase from a strict marine bacterium, Vibrio sp. GMD509. Appl. Microbiol. Biotechnol. 77:107-115.

Patel, H. K., Ferrante, P., Covaceuszach, S., Lamba, D., Scortichini, M., and Venturi, V. 2014. The kiwifruit emerging pathogen Pseudomonas syringae pv. actinidiae does not produce AHLs but possesses three LuxR solos. PLoS ONE 9:e87862.

Petriccione, M., Di Cecco, I., Arena, S., Scaloni, A., and Scortichini, M. 2013. Proteomic changes in Actinidia chinensis shoot during systemic infection with a pandemic Pseudomonas syringae pv. actinidiae strain. J. Proteomics 78:461-476.

Petriccione, M., Salzano, A. M., Di Cecco, I., Scaloni, A., and Scortichini, M. 2014. Proteomic analysis of the Actinidia deliciosa leaf apoplast during biotrophic colonization by Pseudomonas syringae pv. actinidiae. J. Proteomics 101:43-62.

Poueymiro, M., and Genin, S. 2009. Secreted proteins from Ralstonia solanacearum: A hundred tricks to kill a plant. Curr. Opin. Microbiol. 12:44-52.

Preston, G. M. 2000. Pseudomonas syringae pv. tomato: The right pathogen, of the right plant, at the right time. Mol. Plant Pathol. 1:263-275.

Reimmann, C., Beyeler, M., Latifi, A., Winteler, H., Foglino, M., Lazdunski, A., and Haas, D. 1997. The global activator GacA of Pseudomonas aeruginosa $\mathrm{PAO}$ positively controls the production of the autoinducer N-butyrylhomoserine lactone and the formation of the virulence factors pyocyanin, cyanide, and lipase. Mol. Microbiol. 24:309-319.

Roine, E., Raineri, D. M., Romantschuk, M., Wilson, M., and Nunn, D. N. 1998. Characterization of type IV pilus genes in Pseudomonas syringae pv. tomato DC3000. Mol. Plant-Microbe Interact. 11:1048-1056.

Romantschuk, M., and Bamford, D. H. 1986. The causal agent of halo blight in bean, Pseudomonas syringae pv. phaseolicola, attaches to stomata via its pili. Microb. Pathog. 1:139-148.

Rosenau, F., and Jaeger, K. 2000. Bacterial lipases from Pseudomonas: Regulation of gene expression and mechanisms of secretion. Biochimie 82:1023-1032.

Rosenau, F., Isenhardt, S., Gdynia, A., Tielker, D., Schmidt, E., Tielen, P., Schobert, M., Jahn, D., Wilhelm, S., and Jaeger, K. E. 2010. Lipase LipC affects motility, biofilm formation and rhamnolipid production in Pseudomonas aeruginosa. FEMS Microbiol. Lett. 309:25-34.

Saile, E., McGarvey, J. A., Schell, M. A., and Denny, T. P. 1997. Role of extracellular polysaccharide and endoglucanase in root invasion and colonization of tomato plants by Ralstonia solanacearum. Phytopathology 87: 1264-1271.

Sambrook, J., Fritsch, E. F., and Maniatis, T. 1989. Molecular Cloning: A Laboratory Manual, 2nd Ed. Cold Spring Harbor Laboratory, Cold Spring Harbor, NY.

Scortichini, M. 1994. Occurrence of Pseudomonas syringae pv. actinidiae on kiwifruit in Italy. Plant Pathol. 43:1035-1038. 
Scortichini, M., Marcelletti, S., Ferrante, P., Petriccione, M., and Firrao, G. 2012. Pseudomonas syringae pv. actinidiae: A re-emerging, multi-faceted, pandemic pathogen. Mol. Plant Pathol. 13:631-640.

Serizawa, S., Ichikawa, T., Takikawa, Y., Tsuyumu, S., and Goto, M. 1989. Occurrence of bacterial canker of kiwifruit in Japan: Description of symptoms, isolation of the pathogen and screening of bactericides. Ann. Phytopathol. Soc. Jpn. 55:427-436.

EPPO. 2011. First report of Pseudomonas syringae pv. actinidiae in Switzerland. EPPO Reporting Service 2011/130. http://archives.eppo.int/ EPPOReporting/2011/Rse-1108.pdf

Smeltzer, M. S., Hart, M. E., and Iandolo, J. J. 1992. Quantitative spectrophotometric assay for staphylococcal lipase. Appl. Environ. Microbiol. 58:2815-2819.

Staskawicz, B., Dahlbeck, D., Keen, N., and Napoli, C. 1987. Molecular characterization of cloned avirulence genes from race 0 and race 1 of Pseudomonas syringae pv. glycinea. J. Bacteriol. 169:5789-5794.

Suoniemi, A., Björklöf, K., Haahtela, K., and Romantschuk, M. 1995. Pili of Pseudomonas syringae pathovar syringae enhance initiation of bacterial epiphytic colonization of bean. Microbiology 141:497-503.

Taguchi, F., and Ichinose, Y. 2011. Role of type IV pili in virulence of Pseudomonas syringae pv. tabaci 6605: Correlation of motility, multidrug resistance, and HR-inducing activity on a nonhost plant. Mol. PlantMicrobe Interact. 24:1001-1011.

Takikawa, Y., Serizawa, S., Ichikawa, T., Tsuyumu, S., and Goto, M. 1989. Pseudomonas syringae pv. actinidiae pv. nov.: The causal bacterium of canker of kiwifruit in Japan. Ann. Phytopathol. Soc. Jpn. 55:437-444.

Tamir-Ariel, D., Rosenberg, T., Navon, N., and Burdman, S. 2012. A secreted lipolytic enzyme from Xanthomonas campestris pv. vesicatoria is expressed in planta and contributes to its virulence. Mol. Plant Pathol. 13:556-567.

Templeton, M. D., Warren, B. A., Andersen, M. T., Rikkerink, E. H., and Fineran, P. C. 2015. Complete DNA sequence of Pseudomonas syringae pv. actinidiae, the causal agent of kiwifruit canker disease. Genome Announc. 3(5):e01054-15.

Urban, A., Leipelt, M., Eggert, T., and Jaeger, K. E. 2001. DsbA and DsbC affect extracellular enzyme formation in Pseudomonas aeruginosa. J. Bacteriol. 183:587-596.

Vanneste, J. L., Yu, J., and Cornish, D. A. 2010. Molecular characterisations of Pseudomonas syringae pv. actinidiae strains isolated from the recent outbreak of bacterial canker on kiwifruit in Italy. N. Z. Plant Prot. 63:7-14.
Vanneste, J. L., Poliakoff, F., Audusseau, C., Cornish, D. A., Paillard, S., Rivoal, C., and Yu, J. 2011. First report of Pseudomonas syringae pv. actinidiae, the causal agent of bacterial canker of kiwifruit in France. Plant Dis. 95:1311.

Vanneste, J. L., Yu, J., Cornish, D. A., Tanner, D. J., Windner, R., Chapman, J. R., Taylor, R. K., Mackay, J. F., and Dowlut, S. 2013. Identification, virulence and distribution of two biovars of Pseudomonas syringae pv. actinidiae in New Zealand. Plant Dis. 97:708-719.

Voigt, C. A., Schafer, W., and Salomon, S. 2005. A secreted lipase of Fusarium graminearum is a virulence factor required for infection of cereals. Plant J. 42:364-375.

Yang, X., Yi, X. K., Chen, Y., Zhang, A. F., Zhang, J. Y., Gao, Z. H., Qi, Y. J., and $\mathrm{Xu}$, Y. L. 2015. Identification of Pseudomonas syringae pv. actinidiae strains causing bacterial canker of kiwifruit in the Anhui Province of China, and determination of their streptomycin sensitivities. Genet. Mol. Res. 14: 8201-8210.

Yao, J., and Allen, C. 2006. Chemotaxis is required for virulence and competitive fitness of the bacterial wilt pathogen Ralstonia solanacearum. J. Bacteriol. 188:3697-3708

Ye, R. W., Zielinski, N. A., and Chakrabarty, A. M. 1994. Purification and characterization of phosphomannomutase/phosphoglucomutase from Pseudomonas aeruginosa involved in biosynthesis of both alginate and lipopolysaccharide. J. Bacteriol. 176:4851-4857.

Yoon, S. S., Hennigan, R. F., Hilliard, G. M., Ochsner, U. A., Parvatiyar, K., Kamani, M. C., Allen, H. L., DeKievit, T. R., Gardner, P. R., Schwab, U., Rowe, J. J., Iglewski, B. H., McDermott, T. R., Mason, R. P., Wozniak, D. J., Hancock, R. E., Parsek, M. R., Noah, T. L., Boucher, R. C., and Hassett, D. J. 2002. Pseudomonas aeruginosa anaerobic respiration in biofilms: Relationships to cystic fibrosis pathogenesis. Dev. Cell 3:593-603.

Yu, J., Penaloza-Vazquez, A., Chakrabarty, A. M., and Bender, C. L. 1999. Involvement of the exopolysaccharide alginate in the virulence and epiphytic fitness of Pseudomonas syringae pv. syringae. Mol. Microbiol. 33: 712-720.

Yu, J. G., Lim, J. A., Song, Y. R., Heu, S., Kim, G. H., Koh, Y. J., and Oh, C. S. 2016. Isolation and characterization of bacteriophages against Pseudomonas syringae pv. actinidiae causing bacterial canker disease in kiwifruit. J. Microbiol. Biotechnol. 26:385-393. 